Berkala Ilmu Perpustakaan dan Informasi, Vol. 16, No. 2, Desember 2020, Hal. 142-154 DOI: 10.22146/bip.v16i1.424

ISSN 1693-7740 (Print), ISSN 2477-0361 (Online)

Tersedia online di https://journal.ugm.ac.id/v3/BIP

\title{
Identifikasi kecakapan inovasi lembaga riset di Indonesia berbasis dokumen
}

\author{
Aris Yaman ${ }^{1}$, Bagus Sartono ${ }^{2}$, Agus M. Soleh ${ }^{3}$ \\ ${ }^{1}$ Pascasarjana, IPB University \\ ${ }^{2,3}$ Departemen Statistika dan Sain Data, IPB University \\ e-mail:arisyaman@apps.ipb.ac.id
}

Naskah diterima: 22 Juni 2020, direvisi: 7 Oktober 2020, disetujui: 19 Oktober 2020

\begin{abstract}
ABSTRAK
Pendahuluan. Invensi yang dihasilkan lembaga-lembaga riset di Indonesia terindikasi adanya duplikasi. Pemetaan spesialisasi invensi lembaga riset penting untuk dilakukan. Penelitian ini mengkhususkan pada pemetaan kecakapan inovasi lembaga riset di Indonesia.

Metode penelitian. Penelitian ini menggunakan metode analisis dokumen teknologi berbasis paten untuk memetakan potensi teknologi. Data yang digunakan merupakan data paten terdaftar pada database DJKI.

Data analisis. Metadata analisis dilakukan menggunakan metode $K$-means Clusterring dengan bantuan software R.

Hasil dan Pembahasan. Temuan pada pre analisis menunjukkan bahwa ketika peubah bebas yang terlibat dalam model sangat besar, metode Localized feature selection, dapat efektif menseleksi peubah tanpa kehilangan banyak informasi. Hasil analisis menggunakan metadata paten menunjukkan bahwa terdapat 5 kelompok teknologi dominan yang yang mampu dihasilkan oleh lembaga riset di Indonesia, antara 1) Teknologi terkait pengembangan teknologi instrumen pengukuran dan pengujian; 2) Teknologi terkait makanan dan bahan makanan; dan 3) Alat uji mikrostruktural; 4) Radar dan sejenisnya; 5) Teknologi dalam bidang pertanian.

Kesimpulan dan Saran. Temuan menunjukkan bahwa masih terdapat tumpang tindih invensi oleh beberapa lembaga riset yang berbeda pada klaster teknologi yang sama. Selain itu, K-means Clustering dengan pre analisis LFSBSS memiliki performa yang baik dalam memisahkan klaster teknologi dengan jelas.
\end{abstract}

Kata kunci: k-means clustering; paten; teknologi spesialis; metadata analisis

\section{ABSTRACT}

Introduction. Duplication in inventions produced by research institutions in Indonesia becomes an issue. It is important to map the specialization of the invention in research institutions. This study examines the mapping of the innovation in research institutions in Indonesia.

Data Collection Method. This study uses a patent-based technology document analysis method to map the potential of technology. The data used is patent data registered in the Direktorat Jenderal Kekayaan Intelektual (DJKI) database.

Data Analysis. Metadata analysis was conducted by using the K-Means Clustering method with R software.

Results and Discussions. The findings in the pre-analysis show that when the independent variable involved in the model are very large, the Localized feature selection method can effectively select variables without losing much information. There are 5 dominant technology groups that can be produced by research institutions in Indonesia, namely 1) Technology related to the development of measurement and testing instrument technology; 2) Technologies related to food and food ingredients; and 3) microstructural test equipment / detectors; 4) radar technology; 5) Technology in agriculture. 
Conclusion. The findings show that there are still overlapping inventions by several research institutions in the same technology cluster. K-means clustering with LFSBSS pre analysis has a clear performance in the technology cluster space.

Keywords: $k$-means clustering; patent; technology specialist; metadata analysis

\section{A. PENDAHULUAN}

World Economic Forum (WEF) 2019 menuturkan bahwa daya saing bangsa indonesia mengalami penurunan lima level dari periode sebelumnya, dari posisi 45 ke posisi 50 di periode 2018-2019. Salah satu faktor yang menyebabkan rendahnya daya saing Indonesia adalah rendahnya kapasitas bangsa dalam berinovasi, indeks poin dalam kategori ini termasuk rendah hanya 37.7 dalam 100 poin maksimal (Schwab, 2019).

Pemangku kebijakan (Kemenristek/BRIN) kiranya dapat memetakan kecakapan inovasi lembaga-lembaga riset dalam otoritasnya. Saat ini setidaknya ada empat lembaga riset besar dalam koordinasi BRIN yaitu LIPI, BPPT, LAPAN dan BATAN (Presiden RI, 2019). Pemetaan kecakapan inovasi ini penting dilakukan supaya pemangku kepentingan dapat mengetahui arah kebijakan teknologi yang sesuai dengan kapasitas negaranya. Menindaklanjuti adanya tumpang tindih output antar lembaga riset.

Penelitian dan pengembangan suatu lembaga riset dapat ditelusuri melalui dokumen paten yang terdaftar di kantor paten. Paten merupakan hak eksklusif yang diberikan oleh negara kepada inventor atas hasil penemuannya di bidang teknologi, yang selama waktu tertentu melaksanakan sendiri penemuan tersebut atau memberikan persetujuan kepada pihak lain untuk melaksanakannya. Hak paten merupakan salah satu bentuk dari Hak Kekayaan Intelektual (HKI). Paten dapat meningkatkan profitabilitas dan mempertahankan keunggulan kompetitif (Artz et al., 2010).

Dokumen-dokumen paten berisi berbagai informasi teknis yang berkaitan dengan hak kekayaan intelektual dan hasil penelitian (Chen et al., 2017). Sebuah penelitian menunjukkan bahwa negara yang tidak melakukan analisis terhadap data paten berdampak terhadap tingginya biaya dan waktu yang panjang dalam proses pengembangan teknologi (Kim \& Bae, 2017). Oleh karena itu, pemangku kebijakan seharusnya dapat memanfaatkan informasi yang terdapat pada penelitian ilmiah dan pengembangan industri yang telah dipatenkan sebelumnya untuk menentukan arah inovasi bangsa. Dalam hal ini, jika digunakan secara benar, informasi paten dapat menjadi salah satu faktor pendorong utama dalam perkembangan teknologi dan kemajuan sosial. Pemanfatan data paten dapat dijadikan sebagai landasan dalam menyusun roadmap inovasi. Hal ini tidak hanya memainkan peran penting dalam menemukan peluang teknologi baru, menghindari duplikasi investasi $\mathrm{R} \& \mathrm{D}$, mencegah risiko pelanggaran paten, dan sebagainya, tetapi juga memiliki arti penting untuk memandu pengembangan industri secara keseluruhan (Yu \& Zhang, 2019).

Peneliti-peneliti terdahulu telah melakukan penelitian terkait isu-isu paten yang berkembang dari berbagai perspektif. Penelitian paten sebelumnya pada umumnya menggunakan pendekatan metode bibliometrika dalam menganalisis secara kuantitatif literatur ilmiah (B. Wang et al., 2018). Su et al. (2019) menggunakan metode terintegrasi main path analysis untuk menganalisis jalur arah pengembangan di bidang ilmu pengetahuan dan teknologi.

Analisis paten membantu dalam menganalisis kronologi status teknologi saat ini, peramalan tren teknologi, pertumbuhan ekonomi, kapasitas teknologi nasional, daya saing, nilai pasar, kemampuan $\mathrm{R} \& \mathrm{D}$, dan perencanaan strategis untuk menghindari pengeluaran R\&D yang tidak perlu (Y. L. Wang, 2012).

Berbagai penelitian terdahulu yang mengidentifikasi teknologi berbasis dokumen paten. Analisis lebih banyak dilakukan berbasis analisis kata kunci (text mining). Padahal sebuah 
dokumen paten sudah secara global disepakati untuk dicantumkan kode teknologi berdasarkan suatu pedoman tertentu. Pengkodean teknologi pada dokumen paten ini dikenal diengan istilah IPC patent (WIPO, 2018). Diharapkan analisis dengan menggunakan IPC paten lebih konsisten dan dengan tingkat validitas yang lebih baik.

Kajian ini berusaha mengisi gap riset yang terjadi ketika menganalisis hanya berbasis analisis kata kunci. Penelitian ini memfokuskan analisis pada kode IPC yang terdapat dalam dokumen paten.

Mengambil paten yang sesuai dari dataset besar ini adalah suatu yang kompleks. Proses ini dapat disederhanakan jika dapat membagi dataset menjadi kelompok. Analisis klaster merupakan salah satu solusi yang dapat melakukan hal ini (Dhir et al., 2019).

Salah satu aspek yang dapat menimbulkan ambiguitas pada analisis klaster terjadi ketika peubah yang dianalisis cukup banyak. Hal ini berdampak pada sulitnya intrepretasi klaster yang dihasilkan nantinya. Penelitian ini menambahkan pre analisis dengan melakukan seleksi peubah terlebih dahulu sebelum dilakukan analisis klaster. Hasil klaster dengan metode ini lebih mudah untuk ditafsirkan dan intrepretasikan.

Penelitian ini mengidentifikasi teknologi utama pada bidang tertentu dan menemukan bagaimana teknologi dari bidang yang berbeda dapat saling terkait dan terintegrasi. Analisis klasifikasi paten dapat digunakan untuk memetakan alur perkembangan teknologi, masa lalu, masa kini, dan prediksi masa datang, bahkan jauh sebelum produk muncul di pasar.

Tujuan penelitian ini adalah memetakan kecapakan inovasi lembaga riset di Indonesia berbasis paten klaster, menggunakan database paten DJKI Kemenkumham (Direktorat Jenderal Kekayaan Intelektual, Kementerian Hukum dan HAM) melalui analisis IPC (International Patent Classification), sehingga didapatkan area strategis untuk pengembangan inovasi.

\section{B. TINJAUAN PUSTAKA International Patent Classification (IPC)}

International Patent Classification (IPC) merupakan suatu sistem klasifikasi paten secara internasional yang dikembangkan oleh World Intellectual Property Organization (WIPO). Sistem klasifikasi IPC merupakan cara yang paling tepat untuk menggali informasi paten karena pengkategorian dan pengindeksannya yang konsisten. Untuk mengklasifikasikan semua peubah bebas teknologi yang relevan, seluruh paten diklasifikasikan setidaknya oleh satu kode IPC. Ketika terdapat lebih dari satu aspek teknologi yang berbeda dalam satu paten tunggal, maka paten tersebut akan memiliki lebih dari satu kode IPC. Sebagai hasilnya, dapat dengan mudah untuk diidentifikasi berapa banyak teknologi dan bidang teknologi mana yang saling terkait dalam suatu paten. Aplikasi paten di masing-masing bidang menunjukkan akumulasi dari pengetahuan dan kemajuan dalam lintasan teknologi (Fai \& von Tunzelmann, 2001). Oleh karena itu, analisis data kode IPC yang diekstraksi dari dokumen paten memungkinkan untuk memahami perkembangan teknologi dan membuat prediksi tren pengembangan teknologi ke depan.

Kode IPC adalah suatu hirarki yang menetapkan keberadaan paten dalam suatu kategori. Terdapat 8 Seksi, 131 kelas, 642 subkelas, dan 73.915 grup. Adapun 8 Seksi IPC terdiri dari (A) Kebutuhan Manusia (Human Necessities); (B) Pengoperasian, Transportasi (Perfoming Operation, Transportation); (C) Kimia, Metalurgi (Chemistry, Metallurgy); (D) Tekstil, Kertas (Textiles, Paper); (E) Konstruksi (Fixed Constructions); (F) Teknik Permesinan, Penerangan, Pemanasan, Senjata, Peledakan (Mechanical Engineering, Lighting, Heating, Weapons, Blasting); (G) Fisika (Physiscs); (H) Kelistrikan (Electricity). Peneliti menggunakan versi IPC (2018) dalam penelitian ini (WIPO, 2018). Sebagai contoh, definisi dari A61 adalah "Ilmu Medis dan Kedokteran Hewan; Ilmu Kesehatan" dibagi dalam 16 subkelas, antara lain, A61B (Diagnosa, Operasi, dan Identifikasi), A61D (Instrumen, Pengaplikasian, Alat, dan Metode untuk 
Kedokteran Hewan), dan A61K (Persiapan untuk tujuan medis, gigi, atau toilet).

\section{K-Means Clustering}

Dokumen paten dari berbagai invensi merupakan data yang sangat besar dan kompleks. Menjadi rumit jika kita menganalisis dengan metode statitika deskripstif. Proses ini dapat disederhanakan jika dataset dapat dibagi menjadi kelompok. Analisis klaster merupakan solusi yang dapat melakukan hal ini (Dhir et al., 2019). Analisis klaster salah satu metode deskriptif statistik yang bertujuan mengklasterkan objek-objek menjadi beberapa kelompok/klaster, berdasarkan ukuran kemiripan/ketakmiripan antar objek. Berbagai metode digunakan untuk menentukan keanggotaan kelompok dalam analisis klaster. Secara umum analisis klaster dibagi menjadi dua yaitu Analisis Klaster Hierarki dan Analisis Klaster Non-Hirarki.

Salah satu metode analisis klaster non hierarki atau metode partioning yang paling populer adalah Analisis klaster K-means. Pada metode ini banyaknya klaster secara pasti harus sudah diketahui. Sebuah cara sederhana yang dapat digunakan untuk menentukan banyak klaster yang akan digunakan adalah plot dari jumlah kuadrat dalam klaster (within sum of squares) dengan banyak klaster yang mana hasilnya mirip dengan screeplot dalam analisis faktor.

\section{Localized Feature Selection Based on Scatter Separability (LFSBSS)}

Fenomena yang sering terjadi dalam analisis klaster diantaranya terdapat peubahpeubah bebas yang tidak relevan dalam kumpulan data yang dapat mengurangi kualitas akhir pengklasteran dan menghabiskan lebih banyak memori. Oleh karena jika peubah bebas ini dihapus, waktu komputasi dapat dihemat. Dari sudut pandang pengelompokan, menghapus peubah bebas yang tidak relevan tidak akan berdampak negatif pada akurasi pengelompokan sekaligus mengurangi penyimpanan dan waktu komputasi yang diperlukan (Aggarwal, Charu C.; Reddy, 2014).
Ide LFSBSS didasari fenomena bahwa peubah yang relevan dengan satu hasil pengklasteran tidak perlu set yang sama yang relevan dengan hasil pengklasteran lain ( $\mathrm{Li}$ et al., 2008). Dengan kata lain suatu peubah bebas hanya relevan bagi satu atau beberapa klaster yang terbentuk, tidak untuk semua klaster. Li et al.(2008) dalam mengevaluasi kriteria peubah bebas yang relevan dalam suatu klaster, mengadopsi rumusan plot separabilitas yang telah ditemukan sebelumnya.

LFSBSS mengurangi adanya dampak tumpang tindih dan tidak terkategorisasinya suatu amatan dengan memberikan fungsi penalti. Fungsi ini disebut sebagai normalisasi nilai yang dijustifikasi. Nilai proyeksi dengan penalti ini diterapkan jika jumlah amatan yang saling tumpang tindih atau tidak terkategori semakin meningkat dibandingkan dengan nilai proyeksi pengklasteran asli/awal. LFSBSS pada prinsipnya mengadopsi backward feature selection. Hal ini berarti bahwa klaster dibuat terlebih dahulu menggunakan seluruh peubah penjelas, kemudian, secara berulang menghapus peubah penjelas yang tidak relevan (Aggarwal, Charu C.; Reddy, 2014).

\section{Principal Component Analysis (PCA) atau Analisis Komponen Utama (AKU)}

Analisis PCA ini pada dasarnya bertujuan untuk menghilangkan adanya korelasi antar peubah penjelas. PCA memberikan informasi yang cukup dengan sejumlah peubah baru yang lebih sedikit yang saling tegak lurus yang disusun dari kombinasi peubah asal. Dengan kata lain diusahakan didapatkan sejumlah gugus peubah baru yang diolah dari sejumlah peubah lama sedemikian sehingga menghasilakan gugus peubah baru. Gugus baru peubah ini jauh lebih sedikit dibanding banyaknya gugus peubah lama. Peubah baru ini merupakan kombinasi linear dari gugus peubah lama. Peubah-peubah baru yang terbentuk memiliki sifat saling bebas (Markowitz, 2018).

Atas dasar bahwa peubah baru yang terbentuk dari proses PCA ini jauh lebih sedikit dibandingkan jumlah peubah sebelumnya, maka hasil perhitungan peubah baru ini dapat 
diadaptasi untuk analisis lanjutan. Beberapa analisis lanjutan yang memungkinkan yaitu analisis regresi PCA dan Kluster PCA.

Secara matematis tujuan PCA pada dasarnya adalah memutar sumbu ruang $p$ dimensi secara kaku ke posisi baru (sumbu utama) yang memiliki sifat yaitu sedemikian rupa sehingga sumbu utama 1 memiliki varian tertinggi, sumbu 2 memiliki varian tertinggi berikutnya, dan sumbu $p$ memiliki varian terendah. Kovariansi di antara setiap pasang sumbu utama adalah nol (sumbu utama tidak berkorelasi) (Johnson \& Wichern, 2007).

Secara konsep teori statistika, pembentukan komponen utama pada prinsipnya merupakan proses terbentuknya kombinasi linear dari peubah-peubah penjelas yang diamati. Oleh karena kombinasi linear tentunya diperlukan suatu metode yang dapat memberikan bobot dari tiap peubah penjelas yang diamati.

Proses mendapatkan nilai-nilai koefisien atau bobot dari kombinasi linier peubah-peubah penjelasnya memiliki ketentuan sebagai berikut, pertama ada sebanyak $\mathrm{p}$ komponen utama, yaitu sebanyak peubah yang diamati dan setiap komponen utama adalah kombinasi linier dari peubah-peubah tersebut. Kedua, setiap komponen utama saling ortogonal (tegak lurus) dan saling bebas. Terakhir, komponen utama dibentuk berdasarkan urutan variansi dari yang terbesar hingga yang terkecil (Zelterman, 2015).

\section{METODE PENELITIAN}

Data yang digunakan dalam penelitian ini merupakan metadata dokumen paten yang terdapat dalam database paten DJKI Kemenkumham (Direktorat Jenderal Kekayaan Intelektual, Kementerian Hukum dan HAM), dengan alamat https://pdkiindonesia.dgip.go.id/. kata kunci dalam pencarian yang digunakan: LIPI, BPPT, BATAN dan LAPAN. Terdapat sebanyak 280 observasi (dokumen paten) yang tersebar pada lima lembaga riset tersebut. Metadata dari 280 dokumen paten ini diklasetrisasi dengan metode K-Means Clustering.

DJKI merupakan satu-satunya insititusi di Indonesia yang diberikan mandat oleh pemerintah dalam mengelola dan memverifikasi paten (Presiden Republik Indonesia, 2016). LIPI, BPPT, BATAN dan LAPAN merupakan lembaga riset terbesar di Indonesia sehingga dipilih sebagai objek dalam penelitian ini.

Analisis lebih lanjut dilakukan khususnya terhadap kode IPC dalam metadata dokumen paten. Penyampaian metode analisis yang dilakukan dalam kajian ini digambarkan dalam bentuk diagram alir seperti tampak pada Gambar 1.

Diagram alir penelitian yang terdapat dalam Gambar 3 dapat dinarasikan sebagai berikut:

1. Identifikasi banyaknya peubah penjelas yang akan diteliti dalam mencari fenomena tertentu

2. Identifikasi apakah jumlah peubah yang dianalisis banyak dan atau melebihi banyaknya amatan. Hal ini penting dilakukan karena apabila terjadi jumlah amatan lebih sedikit dibandingkan jumlah peubah penjelas menyebabkan terbentuknya matriks singular. Hal ini berdampak tidak akan didapat solusi penyelesaian.

3. Jika terjadi fenomena pada langkah 2, maka perlu dilakukan pre analasis, peneliti menerapkan pre analisis dengan PCA. Jika prosedur PCA masih menimbulkan multitafsir ketika dilakukan analisis lanjutan dengan $K$-means Clustering, maka perlu dilakukan pre analisis dengan pendekatan LFSBSS.

4. Jika dirasa pre analisis dengan PCA dan atau LFSBSS cukup informatif, kita lakukan pengklasteran berdasarkan hasil seleksi peubah yang telah dilakukan pada tahap PCA dan atau LFSBSS.

5. Melakukan analisis klaster dengan metode K-Means Clustering. Secara ringkas metode ini dapat dijelaskan sebagai berikut:

a. Masukan sebanyak 280 dataset paten kedalam algoritma k-means. Tentukan sejumlah p peubah bebas hasil seleksi peubah, baik dengan metode PCA dan atau dengan LFSBSS

b. Tentukan banyaknya klaster yang ingin dibentuk (penelitian ini dilakukan 
dengan pendekatan screeplot)

c. Tentukan ukuran pemusatan klaster (centroid) untuk setiap klaster yang yang ditentukan pada tahap sebelumnya

d. Ukur jarak setiap observasi dengan centroid pada tahap sebelumnya

e. Kelompokkan setiap observasi berdasarkan jarak terkecil

f. Identifikasi apakah observasi berpindah klaster

g. Jika tidak terjadi lagi pemidahan posisi observasi, klaster yang terbentuk sudah valid, jika masih terdapat perpindahan observasi ke klaster yang lain, ulangi dimulai dari langkah d).

6. Intrepretasi hasil.

\section{HASILDAN PEMBAHASAN}

\section{Distribusi Kecakapan Inovasi Lembaga Riset Indonesia}

LIPI menjadi lembaga riset yang memiliki tingkat produktivitas paten tertinggi dibanding tiga lembaga litbang lainnya. Lima Puluh satu persen dari keseluruhan paten lemlitbang diproduksi oleh LIPI, dikuti Batan dengan perolehan $24 \%$ paten nasional, kemudian BPPT sebesar $21 \%$, dan yang masih dalam tahap perkembangan yaitu LAPAN sekitar 4\% dari total paten lembaga litbang (Gambar 2). Hal ini mengindikasikan bahwa LIPI mempunyai SDM yang cukup cakap dalam berbagai kategori teknologi dan paling produktif dalam menghasilkan paten dibandingkan tiga lembaga litbang lainnya.

Gambar 2 (bagian distribusi berdasarkan kategori teknologi), memperlihatkan distribusi kategori inovasi lembaga $\mathrm{RnD}$ di Indonesia. Gambar tersebut memperlihatkan secara global, kategori invensi lembaga litbang di Indonesia didominasi oleh invensi dengan IPC tipe A61 (ilmu kesehatan atau veteriner), A23 (makanan atau bahan makanan) dan C12 (biokimia; mikrobiologi; enzimologi; mutasi atau teknik genetic), dengan persen kontribusi terurut sebesar $13 \%, 9 \%$ dan $8 \%$. Hal ini sejalan dengan perkembangan industri farmasi di tanah air. Sebessar $73 \%$ pangsa pasar farmasi nasional didominasi oleh perusahaan farmasi lokal
(Mubarok, 2017).

Gambar 4, diagram kue bagian kategori invensi juga memberikan suatu indikasi bahwa 3 teknologi dominan atau teknologi yang paling banyak dikembangkan di Indonesia hanya sebesar 30\%. Sedangkan sebanyak 70\% teknologi lainnya menyebar beragam diberbagai kategori teknologi. Hal ini mengindikasikan lembaga-lemabaga riset pada empat lembaga ini belum memiliki fokus teknologi yang jelas. Dengan kondisi sumber daya dan ketertinggalan riset Indonesia saat ini, sulit rasanya jika kita dapat mengembangkan teknologi yang beragam dengan maksimal. Hal ini menjadi gambaran perlunya memusatkan kembali fokus pengembangan suatu teknologi di Indonesia. Dalam menilai dan atau menentukan pusat kecakapan teknologi per lembaga dianalisis lebih lanjut dengan metode $K$-means Clustering dengan pre analisis LFSBSS pada analisis berikutnya.

\section{Pengklasteran Kecakapan Inovasi Nasional}

Dalam kasus ini terdapat sejumlah 69 peubah bebas (contoh H01, A23, A01, A01, C08, C08, B27, B27, C11, C08, G01, B27, G10, B27, B81, G06) (penjelasan kode lihat WIPO, 2018) dengan 280 observasi yang akan dianalisis lebih lanjut. Analisis lanjut yang digunakan dalam kajian ini menggunakan metode K-means Clustering.

Sebelum melakukan analisis klaster kmeans, diasumsikan bahwa jumlah peubah bebas yang dianalisis termasuk besar, sehingga perlu dilakukan pre analisis terlebih dahulu untuk mereduksi jumlah peubah bebas tanpa kehilangan yang berarti persen keragaman model (perhatikan diagram alur analisis pada Gambar 3).

Setelah dilakukan pre analisis dengan LFSBSS, diketahui bahwa dari 69 peubah bebas terseleksi sebanyak 8 peubah bebas yang memiliki tingkat kontribusi yang signifikan terhadap model (table 1). Peubah bebas hasil seleksi dianalisis lebih lanjut yaitu H01, A23, A01, B27, C11, G01, G10, B81. Dengan sejumlah delapan peubah bebas diharapkan memudahkan interpretasi klaster. Apabila kita bandingkan analisis pada Gambar 2 dan Tabel 1, 
terlihat bahwa kategori teknologi dominan A61 dan $\mathrm{C} 12$ tidak masuk dalam filter dengan LFSBSS. Hal ini mengindikasikan bahwa teknologi kategori A61 dan $\mathrm{C} 12$ bukan merupakan peubah pembeda atau peubah pemisah yang dapat memisahkan dengan jelas antar klaster teknologi yang terbentuk. Berdasarkan hal ini, penelitian-penelitian sebelumnya yang berbasis bibliometrik dengan analisis hanya mendasarkan pada nilai paling tinggi/paling banyak muncul pada kategori tertentu, menjadi riskan untuk diambil sebagai dasar kebijakan. Hal ini karena dalam metadata yang dianalisis pada penelitian ini ditemukan fenomena, teknologi yang dominan/paling besar belum tentu merupakan teknologi pembeda yang menjadi dasar pusat kecakapan teknologi. Bahkan apabila kita elaborasi lebih lanjut, A61 dan C12 ini merupakan kategorikategori teknologi yang diteliti oleh banyak institusi lembaga riset. Dengan kata lain indikasi tumpang tindih riset terjadi pada kategori teknologi ini. Hasil LFSBSS pada Tabel 1. juga memberikan gambaran teoritis bahwa metode ini dapat dengan jelas dan baik memisahkan mana peubah yang dapat menjadi peubah pemisah dalam pembentukan klaster nantinya.

Delapan peubah bebas ini dianalisis lebih lanjut dengan prosedur $k$-means clustering. Penentuan jumlah klaster efektif didasarkan pada scree plot antara banyaknya klaster dan jumlah kuadrat dalam klaster. Jumlah klaster efektif didapati ketika penambahan jumlah klaster tidak lagi menambah jumlah kuadrat dalam klaster secara signifikan. Secara grafik hal ini terlihat ketika kurva pada screeplot mulai melandai. Pada kondisi ini jumlah klaster terbaik didapatkan. Gambar 3. memperlihatkan secara visual kurva mulai melandai disaat jumlah klaster sebanyak tujuh. Oleh karena itu, ditentukan jumlah klaster sebesar tujuh $(\mathrm{k}=7)$ dalam analisis $K$-means Clustering.

Setelah didapat jumlah klaster optimum sebanyak tujuh, dilakukan analis klaster kmeans. Hasil analisis klaster dengan metode kmeans dapat dilihat pada Tabel 2. Data pada Tabel 2, menampilkan hasil analisis klaster terhadap metadata dokumen paten pada lembaga-lembaga riset di Indonesia. Nampak lima klaster yang jelas pemisahannya yaitu Klaster 1, 2 dengan 3, 4, 5 dan klaster 6. Dilihat dari sisi keragaman yang dapat dijelaskan model, pengklasteran dalam penelitian ini dapat dikategorikan baik, karena keragaman dalam klaster dapat menjelasakn sebesar $82.9 \%$ terhadap keragaman total.

Melalui Tabel 2, dapat diinterpretasikan setiap klaster yang terbentuk yaitu,

1. Klaster 1, klaster ini berkaitan dengan invensi mengenai instrumen pengukuran dan pengujian

2. Klaster 2 dan 3, berkaitan dengan invensi berhubungan dengan makanan atau bahan makanan

3. Klaster 4, klaster invensi unsur kelistrikan dasar yang berhubungan dengan pengukuran, pengujian dan teknologi mikrostruktural. Dengan kata lain alat uji/detektor mikrostruktural

4. Klaster 5, berkait dengan invensi kelistrikan dasar mengenai radar dan sejenisnya

5. Klaster 6, klaster terkait teknologi pertanian dalam arti luas

6. Klaster 7, klaster teknologi lainnya, yang merupakan kolaborasi lebih dari dua kategori teknologi.

Hasil klasterisasi setiap observasi (dokumen paten) terhadap salah satu dari ketujuh klaster dapat ditabulasi silangkan terhadap lembaga riset pemilik paten tersebut. Hal ini dilakukan untuk memetakan kecakapan tiap lembaga riset terhadap klaster teknologi yang terbentuk.

Tabel 3 memperlihatkan terjadinya indikasi adanya tumpang tindih riset antar lembaga. Kemungkinan besar terjadi tumpang tindih riset yang menghasilkan output paten, terjadi pada klaster teknologi 7. Hal ini disebabkan keempat lemabag riset tersebut sebagian paten termasuk dalam klaster teknologi 7. Temuan ini sejalan dengan penelitian terdahulu bahwa penggunaan anggaran riset diduga mengalami penyimpangan dalam bentuk penelitian fiktif, tumpang tindih aktivitas, pemotongan dana antara 10\%-50\%, pemberian dan penggunaannya tidak sesuai aturan, dan pengendapan anggaran (Dalilah \& Pratama, 2019). 
Tabel 3, dengan mengabaikan klaster 7 (klaster teknologi tumpang tindih), dapat kita identifikasi spesialisasi tiap lembaga riset berdasar klaster yang terbentuk, BATAN tampak pada Tabel 3 memiliki spesialiasi teknologi terkait radar/alat kelistrikan dasar (klaster 4). BPPT memiliki spesialisasi teknologi berhubungan dengan pertanian (Klaster 6). LAPAN secara proporsi sebagian besar teknologi terkait radar dan alat pengukuran. Sementara LIPI dari sisi proporsi, terbesar invensi terkait makanan dan bahan makanan (klaster 2 dengan 3 ).

Apabila diidentifikasi dari sisi banyaknya output paten terhadap klaster teknologi, terlihat bahwa LIPI merupakan lembaga riset yang paling produktif menghasilkan paten dari berbagai klaster/kategori invensi. Hal ini secara kebijakan seperti dua sisi mata uang. Pertama boleh jadi LIPI merupakan lembaga riset yang paling produktif. Kedua, pada sisi lain boleh jadi LIPI kurang memiliki spesialisasi teknologi yang jelas jika dibandingkan dengan tiga lembaga riset lainnya. Dampak strategis dari hasil temuan ini pemangku kebijakan lebih baik menciptakan ekosistem riset yang berbasis kolaborasi antar lembaga jika terdapat lebih dari satu lembaga riset pada posisi klaster teknologi yang sama. Hal ini dimaksudkan untuk menciptakan teknologi yang berdampak besar, signifkan, nyata dan tidak duplikasi. Selain itu dapat kita analisis bahwa $K$-means Clustering dengan pre analisis menggunakan LFSBSS dapat memberikan gambaran yang informatif dan tidak multitafsir dalam memetakan invensi lembaga riset.

Apabila dibandingkan metode $K$-means Clusterring dengan pre analisis LFSBSS pada penelitian ini, dengan metode analisis dengan social network analisis yang dilakukan Chang (2017), terlihat bahwa metode analisis yang dilakukan dalam penelitian ini jauh lebih memudahkan dalam intrepretasi dan narasi hasil analisis. Penelitian sejenis dilakukan terdahulu oleh Madani \& Weber (2016), terlihat identifikasi kecakapan teknologi yang dilakukan hanya didasarkan pada banyakya kemunculan suatu kata teknologi dalam suatu metadata paten. Metode seperti ini dirasa kurang valid dan berisiko jika diambil sebagai dasar kebijakan, karena tanpa melihat jejaring dengan teknologi lainnya. Dengan kata lain identifikasi kecakapan teknologi sebaiknya dikaitkan dengan keterkaitan antar teknologi. Hal ini karena saat ini hampir dikatakan mustahil bahwa suatu teknologi berdiri sendiri.

Penelitian yang dilakukan oleh $\mathrm{Lu} \& \mathrm{Liu}$ (2016), dapat dengan baik mengidentifikasi pusat kecakapan teknologi, tetapi dalam mengintrepretasikan hasil analisis cukup sulit. Hal ini dikarenakan suatu kelompok teknologi sangat rumit sekali berinteraksi dengan teknologi lainnya. Hal ini berdampak pada keragu-raguan dalam menilai dimana letak pusat kecakapan teknolgi dalam suatu klaster teknologi yang terbentuk.

Penelitian terdahulu yang mengkaji terkait identifikasi pusat teknologi berbasis dokumen paten terkhusus teknologi informasi dan komunikasi pernah dilakukan Noh et al (2016). Dalam temuannya, melalui teknik analisis coupling bibliografi dan dan text mining dapat diidentifikasi pusat teknologi yang berpotensi berkembang di masa yang akan datang. Sama halnya dengan penelitian X. Wang \& Duan (2011) pada dasarnya penelitian ini menerapkan keyword analisis dalam mengidentifikasi suatu pusat teknologi dalam apalikasi paten. Padahal dalam dokumen paten-sudah diidentifikasi pusat teknologi berdasarkan kode teknologi IPC WIPO yang sudah disepakati secara global.

Berdasarkan hal ini peneliti mengklaim dengan teknik analisis yang digunakan dalam penelitian ini memperbaiki kelemahan pada penelitian terkait sebelumnya. Hal ini dapat kita lihat bahwa K-means Clustering dengan LFSBSS, keterkaitan antar teknologi masih dapat terlihat dan aspek kemudahan intrepretasi lebih sederhana dan tidak multitafsir dibandingkan Social Network Analysis (SNA). Penelitian ini juga menerapkan analisis pada kode IPC sehingga hasil analisis dirasa lebih valid dibandingkan dengan analisis berbasis text mining.

\section{E. KESIMPULAN}

Berdasarkan paparan sebelumnya dapat dilihat bahwa klaster teknologi lembaga riset 
Indonesia mengkhususkan pada 1) Teknologi terkait pengembangan teknologi instrumen pengukuran dan pengujian; 2) Teknologi terkait makanan dan bahan makanan; dan 3) alat uji/detektor mikrostruktural; 4) Radar dan sejenisnya; dan 5) Teknologi dalam bidang pertanian. Hal lainnya dapat ditemukan masih terdapat indikasi tumpang tindih tema riset antar lembaga riset. Perlunya penciptaan ekosistem riset yang berbasis kolaborasi antar lembaga jika terdapat lebih dari satu lembaga riset pada posisi klaster teknologi yang sama. Hal ini ditujukan agar riset yang dihasilkan berdampak besar, signifikan, nyata, dan tidak tumpang tindih. Dilihat dampak teoritis, kajian ini menemukan bahwa peubah penjelas yang dominan belum tentu menjadi peubah kandidat penentu pemisah pembentukan klaster. Metode LFSBSS dapat menjelaskan fenomena ini dengan baik. LFSBSS mampu menyederhanakan 69 peubah penjelas menjadi hanya 8 peubah penjelas, tanpa kehilangan informasi yang berarti.

Penelitian selanjutnya disarankan untuk mengkombinasikan analisis $K$-means Clustering LFSBSS dengan metode analisis Social Network Analysis. Hal ini dimaksudkan untuk melihat sisi keterkaitan antar jejaring teknologi dan jejaring aktor penemu teknologi. Dengan adanya informasi jejaring teknologi dapat dilihat fenomena kolobarasi riset dan kemungkinan terciptanya distruptif teknologi.

\section{Ucapan Terima Kasih}

Ungkapan terima kasih disampaikan kepada Kementerian Riset dan Teknologi/BRIN atas program Beasiswa SAINTEK, kesempatan dan fasilitas yang diberikan.

\section{DAFTAR PUSTAKA}

Aggarwal, Charu C.; Reddy, C. K. (2014). Data clustering algorithms and applications (Whole Book) (C. K. Aggarwal, Charu C.; Reddy (ed.)). Taylor \& Francis.

Artz, K. W., Norman, P. M., Hatfield, D. E., \& Cardinal, L. B. (2010). A longitudinal study of the impact of R\&D, patents, and product innovation on firm performance. Journal of Product Innovation Management, 27(5), 725-740. https://doi.org/10.1111/j.15405885.2010.00747.x
Chang, S. (2017). Technological forecasting \& social change the technology networks and development trends of university-industry collaborative patents. Technological Forecasting \& Social Change, 118, 107-113. https://doi.org/10.1016/ j.techfore.2017.02.006

Chen, H., Zhang, G., Zhu, D., \& Lu, J. (2017). Topic-based technological forecasting based on patent data: A case study of Australian patents from 2000 to 2014. Technological Forecasting and Social Change, 119, 39-52. https://doi.org/ 10.1016/j.techfore.2017.03.009

Dalilah, E., \& Pratama, F. (2019). Permasalahan dan rumusan perbaikan pengelolaan dana penelitian di Indonesia. Integritas, 6(1), 109-124.

Dhir, S., Kumar, D., \& Singh, V. B. (2019). Success and failure factors that impact on project implementation using agile software development methodology. In M. . Hoda (Ed.), Advances in Intelligent Systems and Computing (731st ed., Vol. 731). springer. https://doi.org/10.1007/978-98110-8848-3 62

Johnson, R. A., \& Wichern, D. W. (2007). Applied multivariate statistics (6th ed.). Pearson Prentice Hall.

Kim, G., \& Bae, J. (2017). A novel approach to forecast promising technology through patent analysis. Technological Forecasting and Social Change, 117, 228-237. https://doi.org/10.1016/j.techfore.2016.11. 023

Li, Y., Dong, M., \& Hua, J. (2008). Localized feature selection for clustering. Pattern Recognition Letters, 29(1), 10-18. https://doi.org/10.1016/j.patrec.2007.08.0 12

Lu, L. Y. Y., \& Liu, J. S. (2016). Technological Forecasting \& social change a novel approach to identify the major research themes and development trajectory : The case of patenting research. Technological Forecasting \& Social Change, 103, 71-82. https://doi.org/10.1016/j.techfore.2015.10. 018 
Madani, F., \& Weber, C. (2016). The evolution of patent mining : Applying bibliometrics analysis and keyword network analysis. World Patent Information, 46, 32-48. https://doi.org/10.1016/j.wpi.2016.05.008

Markowitz, J. S. (2018). Multivariate analysis. Statstics Reference Online, 71-81. https://doi.org/10.1007/978-3-319-7720358

Mubarok, M. F. (2017). Top 10 Perusahaan Farmasi Terbesar Indonesia. h t t p s://farmasi ind ustri.com. https://farmasiindustri.com/industri/top10-perusahaan-farmasi-indonesia.html

Noh, H., Song, Y. K., \& Lee, S. (2016). Identifying emerging core technologies for the future: Case study of patents published by leading telecommunication organizations. Telecommunications Policy, 40(10-11), 956-970. https://doi.org/ 10.1016/j.telpol.2016.04.003

Presiden Republik Indonesia. (2016). UndangUndang No 13 Tahun 2016. Paten (Issue 1). http://www.dgip.go.id/images/kiimages/pdf-files/uu pp1/UU-nomor-13tahun-2016-tentang-paten.pdf

Presiden RI. (2019). Peraturan Presiden Republik Indonesia No 74 Tahun 2019 tentang Badan Riset dan Inovasi Nasional (Issue 009525).

Schwab, K. (2019). The Global Competitiveness Report 2019. http://www3.weforum.org/ docs/WEF TheGlobalCompetitiveness Report2019.pdf

Su, F. P., Chen, S. J., Chang, Y. H., \& Lai, K. K. (2019). Construct a three-stage analysis model of integrated main path analysis and patent family-exploring the development of blockchain. ACM International Conference Proceeding Series, 151-156. https://doi.org/10.1145/3374549.3374583
Wang, B., Liu, Y., Zhou, Y., \& Wen, Z. (2018). Emerging nanogenerator technology in China: A review and forecast using integrating bibliometrics, patent analysis and technology roadmapping methods. Nano Energy, 46, 322-330. https://doi.org/ 10.1016/j.nanoen.2018.02.020

Wang, X., \& Duan, Y. (2011). Identifying core technology structure of electric vehicle industry through patent co-citation information. Energy Procedia, 5, 2581-2585. https://doi.org/10.1016/ j.egypro.2011.03.443

Wang, Y. L. (2012). Research on technology selection for enterprises with tools of patent analysis. International Conference on Management Science and Engineering Annual Conference Proceedings, 1, 1651-1657. https://doi.org/10.1109/ ICMSE.2012.6414394

WIPO. (2018). Guide to the international patent classification. WIPO (World Intellectual Property Organization). https://www.wipo.int/export/sites/www/cl assifications/ipc/en/guide/guide ipc.pdf.

Yu, X., \& Zhang, B. (2019). Obtaining advantages from technology revolution: A patent roadmap for competition analysis and strategy planning. Technological Forecasting and Social Change, 145(April), 273-283. https://doi.org/ 10.1016/j.techfore.2017.10.008

Zelterman, D. (2015). Applied multivariate statistics with R. In M. Gail, J. M. Samet, A. Tsiatis, \& W. Wong (Eds.), Applied Multivariate Statistics with $R$. springer. https://doi.org/10.1007/978-3-319-140933 


\section{DAFTAR GAMBAR}

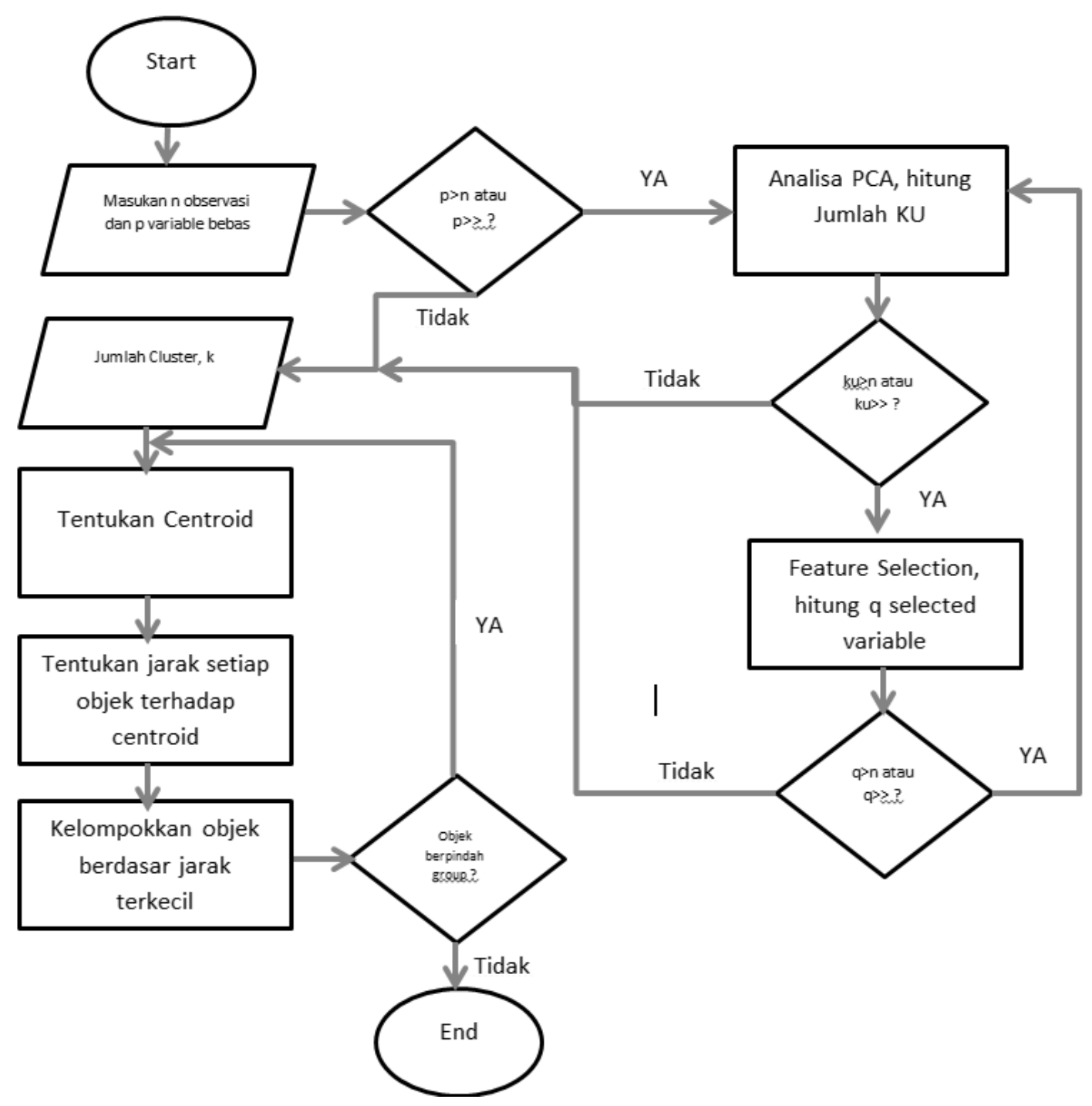

Gambar 1. Diagram Alir Analisis

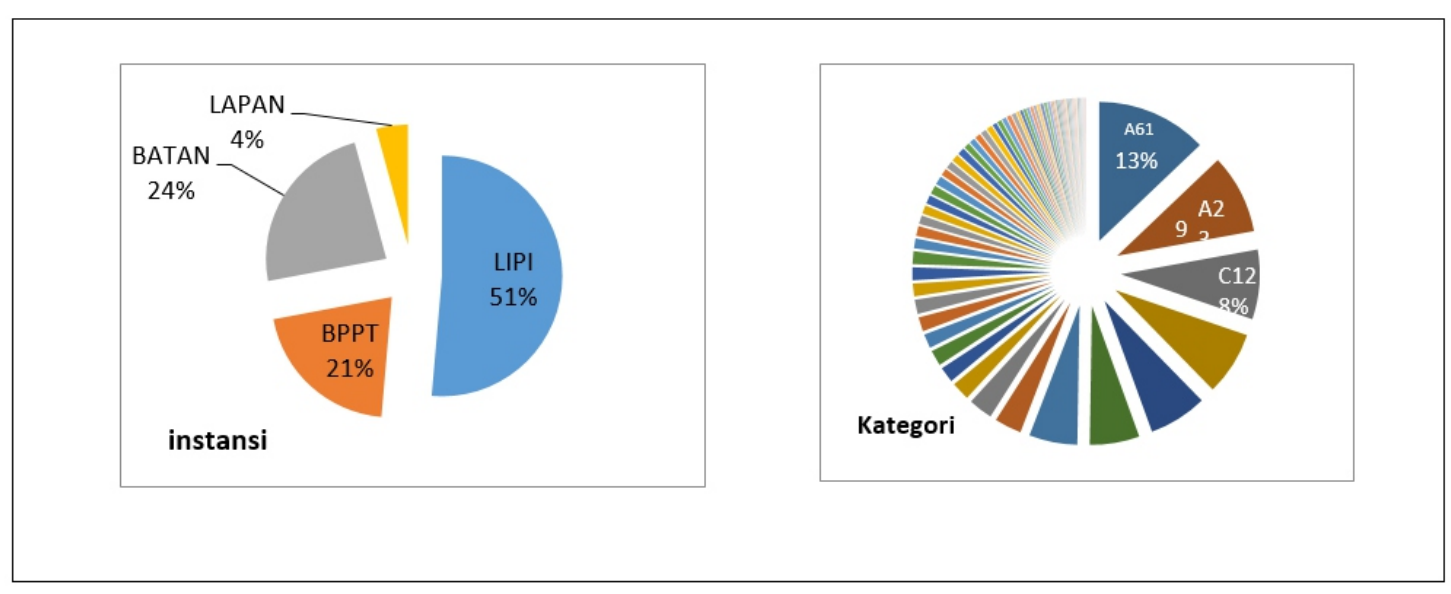

Gambar 2. Distribusi Paten Nasional 


\section{DAFTAR GAMBAR}

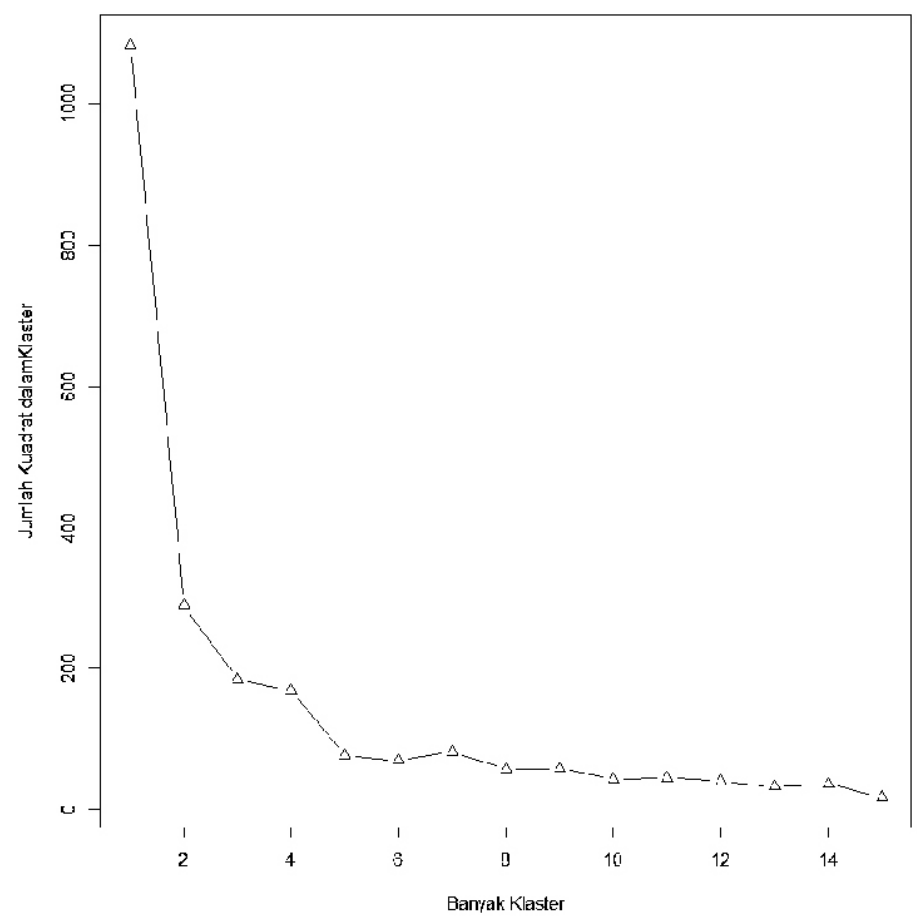

Gambar 3. Scree Plot Penentuan Jumlah Klaster (Sumber : Data diolah, 2019)

DAFTAR TABEL

Tabel 1. Localized feature selection for clustering

\begin{tabular}{llrlrrl}
\hline Peubah proposed & Type of step & \multicolumn{1}{c}{ BICclust } & Model & \multicolumn{1}{c}{ G } & \multicolumn{1}{c}{ BICdiff } & Decision \\
\hline H01 & Add & 737.7576 & E & 5 & 1208.596 & Accepted \\
A23 & Add & 1751.3041 & EII & 9 & 1584.0388 & Accepted \\
A01 & Add & 2939.7359 & EII & 13 & 1580.4901 & Accepted \\
A01 & Remove & 1751.3041 & EII & 9 & 1580.4901 & Rejected \\
C08 & Add & 4066.1556 & EII & 20 & 1611.3606 & Accepted \\
C08 & Remove & 2939.7359 & EII & 13 & 1611.3606 & Rejected \\
B27 & Add & 4656.4015 & EII & 20 & 205.5406 & Accepted \\
B27 & Remove & 4066.1556 & EII & 20 & 205.5406 & Rejected \\
C11 & Add & 5392.9184 & EII & 20 & 351.8116 & Accepted \\
C08 & Remove & 5985.0568 & EII & 15 & -107.1974 & Accepted \\
G01 & Add & 7250.6849 & EII & 19 & 1674.2668 & Accepted \\
B27 & Remove & 5669.7642 & EII & 18 & 1196.2153 & Rejected \\
G10 & Add & 8867.2323 & EII & 20 & 1231.8421 & Accepted \\
B27 & Remove & 7250.6849 & EII & 19 & 1231.8421 & Rejected \\
B81 & Add & 10575.7184 & EII & 20 & 935.6184 & Accepted \\
B81 & Remove & 8867.2323 & EII & 20 & 935.6184 & Rejected \\
G06 & Add & 10537.1101 & EII & 20 & -426.3406 & Rejected \\
B81 & Remove & 8867.2323 & EII & 20 & 935.6184 & Rejected \\
\hline
\end{tabular}

Sumber: Data primer diolah, 2019 


\section{DAFTAR TABEL}

Tabel 2. Rangkuman Analisis Klaster

\begin{tabular}{ccccccccc}
\hline Klaster Means & H01 & A23 & A01 & B27 & C11 & G01 & G10 & B81 \\
\hline 1 & 0.00 & 0.00 & 0.00 & 0.00 & 0.00 & 2.08 & 0.00 & 0.00 \\
2 & 0.00 & 1.43 & 0.00 & 0.00 & 0.00 & 0.00 & 0.00 & 0.00 \\
3 & 0.00 & 3.29 & 0.00 & 0.00 & 0.00 & 0.00 & 0.00 & 0.00 \\
4 & 1.33 & 0.00 & 0.00 & 0.00 & 0.00 & 0.07 & 0.00 & 0.07 \\
5 & 3.75 & 0.00 & 0.00 & 0.00 & 0.00 & 0.00 & 0.00 & 0.00 \\
6 & 0.00 & 0.00 & 2.30 & 0.00 & 0.00 & 0.00 & 0.00 & 0.00 \\
7 & 0.00 & 0.00 & 0.05 & 0.01 & 0.01 & 0.08 & 0.01 & 0.00 \\
\hline
\end{tabular}

Within klaster sum of squares by klaster:

[1] $0.92307695 .65217393 .42857145 .2000000 \quad 2.7500000 \quad 4.100000037 .9711538$ (between_SS / total_SS $=82.9 \%$ )

Sumber: Data primer diolah, 2019

Tabel 3. Tabulasi Silang Klaster Teknologi terhadap Pemilik Paten

\begin{tabular}{ccccc}
\hline \multirow{2}{*}{ Klaster } & \multicolumn{4}{c}{ Jumlah Paten } \\
\cline { 2 - 5 } & BATAN & BPPT & LAPAN & LIPI \\
\hline 1 & 4 & 2 & 2 & 5 \\
2 & 0 & 3 & 0 & 20 \\
3 & 0 & 2 & 0 & 5 \\
4 & 6 & 2 & 2 & 5 \\
5 & 1 & 0 & 0 & 3 \\
6 & 2 & 4 & 0 & 4 \\
7 & 49 & 41 & 5 & 113 \\
\hline
\end{tabular}

Sumber : Data primer diolah, 2019 